\title{
Of Rites of Narration and Representation of the Orient and theOccident in Thomas Heywood's The Faid Maid of the West
}

\author{
Tarik Bouguerba
}

Assistant professor, Ibn Tofail University, Morocco tarik.bouguerba@uit.ac.ma

Received: 03 May 2021; Received in revised form: 05 Jun 2021; Accepted: 11 Jun 2021; Available online: 22 Jun 2021 (C)2021 The Author(s). Published by Infogain Publication. This is an open access article under the CC BY license (https://creativecommons.org/licenses/by/4.0/).

\begin{abstract}
Writing both in prose and verse, Thomas Heywood was one of the most prolific playwrights in the period as was Shakespeare in particular. Heywood was well informed about Morocco and could write in greater detail about a possible dialogue among cultures. As it is a historical platform for power relations, The Fair Maid of the West recalled the heroism and excitement of English counterattacks against Spain in the Post-Armada period. This paper therefore pins down the acts of narration and representation of Morocco and Moroccans and attests to the metamorphosis the plot undergoes in Part I and Part II. As an adventure play, The Fair Maid of the West teaches about, informs of and confirms the existing patterns of virtue in European voyages and at the same time it asserts how honor and chastity are European par excellence whereas villainy and wickedness are Oriental assets by distinction. Once taken captive, these virtues and traits are put into task as the plot disentangles. This paper also examines how the play in both parts generates a whole history of stereotypes about Morocco and unexpectedly subverts this Orientalist tradition; such a biased mode of narration of the Orient the playwright took up at first was played down at a later phase in the narrative.
\end{abstract}

Keywords-Heywood; adventure play; Representation; stereotype; Orientalism; virtue.

\section{INTRODUCTION}

This article examines how Thomas Heywood's The Fair Maid of the West: Part I and II fits within a constant development of our understanding of Islam and early English drama. It also pins down the tactics being deployed by English dramatists as early as earlier theatrical to help understand an essentialist anti-Turk and anti-Muslim bias through an examination of the play and the playwright himself (McJannet et al., 2009:184, 188). From a Saidian point of view, the west has managed from then on to produce many versions of the east. Such an approach, as seminal as Said's, has contributed to our understanding of this everlasting conflict between the Orient and the Occident. Although it has been from then contested and challenged, such a theory would help identify the many ways to examine how Moors, Turks, and even Persians are different at first glance, but all are images of this very other: Although they are identical, they have always resulted in the demonization of the other (2009:185). It was rapidly challenged by Nabil Matar's reading of early modern, Western Europe and the Islamic Mediterranean World. Others emphasized that the claim of cultural, economic, and military superiority at the heart of Orientalism could not apply to the Muslim of North Africa. In line with his objections to Said's theory, Matar (2009:183) still argued that dramatic literature was mainly responsible for generating anti-Islamic and antiMuslim sentiments among the English. Said and his critics would be useful to a deconstructive reading of Thomas Heywood two parts of his text. 
This article offers a full view of Thomas Heywood, who has been described by Louis B. Wright (1935: 650) as the greatest theatrical figure of the Bourgeois ideals of the time, and suggests an examination of his The Fair Maid of the West I and II as two plays that explore how to deal with the social and sexual threats that transglobal commerce is perceived to entail. Thomas Heywood's The Fair Maid of the West, Part I and Part II explore how to exchange with cultural others, and how to do so without establishing exchange generated bonds that corrupt, or more interestingly, compete with and win out over the exchange relations among Englishmen and those between Englishmen and Englishwomen. (Barbra Sebek, 1998: 184)

In a controversial study, Claire Jowitt's Voyage Drama and Gender Politics (Claire Jowitt: MUP2003) explores the use of allegory in Renaissance travel drama. Such a seminal study, as I always like to describe it, describes how travel writing tells two stories. It offers a close ready of events in colonial locations and tells the wishes of the home nation. Jowitt is therefore helpful to our reading of Heywood as her book further develops our understanding of the nature of colonial discourse by critically focusing on the tactics and negotiations between gender and monarchy in geographic or travel drama.

In her other study The Culture of Piracy, 1580-

1630: English Literature and Seasborne Crime (2010:118, 119), Claire Jowitt draws inter-textual attention to the piracy model in Thomas Heywood's play. Bess's piracy, in Part I in particular, is the driving narrative force in the play. Part I also represents, following Claire Jowitt, connections between piracy and Englishness and draws allusion to how pirates helped shape story line in Heywood's narrative.

Together with the plays of the period, Heywood's The Fair Maid of the West I and II has adreamlike adventure plot which moves from England to Fez to Florence and the plot involvesEnglishmen -and English women as well-, Moors and Italians; (Lawrence Dawson, 2002: 2). Through pinning down the acts of narration and representation of the Oriental who is caught in an ongoing conflict with the Occident other inherent in The Fair Maid of the West I and II, the article also takes up an approach where the plays seem to be considered as a modern allegory of the confrontation of the imperial and the capitalist economics of desire in thecommercial, sexual and racial exchanges between the characters. (Garcia, 88:1, 56-69: 58). L.Garcia Garcia (Garcia, 88:1, 56-69: 58) falls in line with Deleuze and Guattari's thoroughexplanation of desire as the constant production of affective and libidinal energy generated by the unconscious in various forms to help understand how Garcia manages to examine how therites of representation of Moors in the play in question were fueled with the desire to contain the fate of the English. For Garcia's perspective, Heywood could be described as the spokesman of this economy of desire which seems to have been informed in both its imperial capitalist and primitive forms.

The article also deems it pertinent to look at different instances of how the value of Bess's fairappearance -the fair English maid- increases once Bess's fairness is exported to foreign lands. Although there is a huge historical gap between the two parts of the play, both seem to suggest that the fair appearance of Bess is exceedingly esteemed by Mullisheg for its superior quality derived from the racialized envisagement. Although of irresistible white form, as it has been described in Orientalism, Heywood seemed to anticipating such Orientalist froms of thisirresistible form of desire on the part of the Moors; which confirms the stereotype that Englishwomen could draw immediate attention from Moors. (Garcia, 88:1, 56-69: 62). In the two parts of the play, the whiteness of Bess has particularly been contrasted to Tota's and Barbary's blackness. This article examines the acts of narration and representation of the

English, Italians and Moors Heywood used in the two parts. It also aims at describing how the academic life of the playwright contributed to the development of the story and it examines how the rhetorics ${ }^{1}$ of desire has become an asset both the English and Moors portrayed, explored and finally tested.

\section{THE PLAYWRIGHT}

To start with, any reading of the two parts of the play would make use of Charles Lamb. Charles Lamb (Ed. Robert K. Turner, Jr. N., 1968: IX) spoke of Thomas Heywood as a sort of prose Shakespeare. ${ }^{2}$ Heywood had always been described as a prose replica of Shakespeare. He was not a Londoner, but like Shakespeare, he went to the theatre. Heywood, unlike Shakespeare, wrote more plays because he lived longer. T.S Eliot, himself, described Heywood's genius as a facile and sometimes felicitous purveyor of goods to the popular taste. (1968: IX)

As Louis B. Wright (Ioppolo, 2014: 126) rightly noted although a few of Heywood's plays were only performed after the Restoration and only into the $18^{\text {th }}$ century, his literary significance was only retained and re-established in the $19^{\text {th }}$ century by Charles Lamb and William Hazlitt. As I have noted earlier, Lamb's eulogy of Heywood as the prose Shakespeare was remarkable, but it did not 
help his reputation on his terms namely through the $20^{\text {th }}$ century. If Heywood's contemporaries have received remarkable editorial attention, Heywood failed to rate even a mention even in titles of books. Being a controversial figure, Heywood's plays seem to have drawn controversies over the ways some of his texts have suffered textual theft including The Fair of Maid of the West. (Williams, 2014: 134). Scholars have daringly suggested that the textual theft Heywood suffered occurred in the printing process of several plays. ${ }^{3}$

In this same introduction by Robert K. Turner, Jr (1968: $\mathrm{X}$ ), it has been claimed that by 1596 , Heywood was writing his very first plays. In his professional career, Heywood may have started as an actor. His first plays were written entirely on his own account. The milieu where he worked made him develop some competence in writing and acting. About his works, Thomas Heywood wrote a play entitled The Foure Prentices Of London in 1594, (Republished in 1615.) This is a play about the crusades, in which Heywood spoke of four Britons who had joined the crusaders. (Matar, 1999:142) The Four Prentices of London is a melodrama of fantastic adventure. (1968: X) His masterpiece, a well known play, was produced in the first two decades of the seventeenth century under the title of The English Traveler (printed in 1633.)

In another play, A Challenge for Beautie, Heywood wrote about the captivity of two English men by the Turks. (1999: 73) Other works of his are The Captives, The Late Lancashire, If You Know not Me, The wise-Woman of Hugsden and A Woman Killed with Kindness. Hardly had age prevented him from his non-dramatic writing, Heywood persisted in prose writing until his death.

Although this article focuses mainly on the acts of narration and representation of Otherness in The Fair Maid of the West, one of Heywood's works that has seen the principal share of critical attention is A Woman killed with Kindness which has eventually become the most repeatedly staged and performed of Heywood's plays, if not his masterpiece. (Ioppolo, 2014:122) This play and his The Fair Maid of the West owe, to a great extent of its popularity,to the rise of gender studies in the 1960's. The play, at issue, falls under Heywood's canon on women. ${ }^{4}$ This owes so much to how the topic of women has become interesting for playwrights.

Probably The Fair Maid of The West, one of his best plays, was written in 1604; which is about the Elizabethan era and the reign of a King of Fez and Great Morocco. Historically, the play alludes to Mulai Sheik, the Moorish king at that very period of history. (1968: XII) Some allusions in the play are distinctly
Elizabethan. In the play, Mullisheg, king of Fez and Great Morocco, points out about Bess's name:

"There is virtue in that name. The virgin queen. So famous through the world, The empress of the maiden isle, Whose predecessors have o'rrun great France, Whose powerful hand doth still support the Dutch And keeps the potent king of Spain in awe." (1968: 8)

This citation is solid evidence that the setting of the play was distinctively Jacobean. Thomas Heywood, in this play, alludes to how Clem undergoes castration at the court of Fez. This seems to be clear evidence of how the play stands as a historical record of the relationship between Moors and Englishmen and English women. As Dawson (Dawson, 2002: 17) has it, in the royal court of Fez are certain Christian captives and a Moroccan king keeps white slaves who are kept by physically-maimed black slaves.

There are two parts in this play; each contains five acts. A reading of the two parts raises the question of their difference; which is due to the circumstances of publication. The play in its entirety is Heywood's, and no piece of evidence is found to determine the exact period of either parts. Part II, as Clark thought in this introduction to the play, might have been written as a sequel to the first in consequence of the court performance. In fine, part II was written some twenty five or thirty years after part I. (1968: XIII)

Authenticity in Heywood is an equivocal issue, provided that the play had not been based on any specific source and its characters' verisimilitude is not even original. ${ }^{5}$ The Life and Pranks of Long Meg of Westminister (1590), an Elizabethan pamphlet, was a first meeting place of Heywood's characters. It could have been of much avail to Bess's initial outline. Spencer The Noble Stranger, Good Lack, the Faithful Friend...... all have been alluded to in dramatic and non-dramatic romance. (1968: 147, XIV) Many are the ocular proofs, to use Iago's words, to confirm the fact that Heywood's play is the outcome of a combination from different works. As is The Fair Maid of the West, other plays of Heywood and his contemporaries, as Dawson alludes to in England, Islam, and the Mediterranean: Othello and Others, make incredible allusion to other plots. For example, if Peele's The Battle of Alcazar makes the English adventurer essential to its depiction of diplomatic relations involving Moors and other European nationalities, Heywood has apparently produced the same plot involving Moors, Englishmen, English women and Italians. (Dawson, 2002: 2).

Mullisheg, The Amorous King of Fez, was used in various renaissance plays, even before the composition of 
part I. He had appeared in the mid- 16th century under different names in plays like Peele's the Battle of Alcazar (1588- 1589). ${ }^{6}$ Some years later, The Fair Maid of the West became a source itself. The English Lovers, or A Girl Worth Gold by John Dauncy is in line with the play under study, given that they share some of the characters. In both plays, Elizabeth (Bess) features as the epitome of the brave noble lover. She is The Leader of The Negro. Half of the title is itself the same. It is the description of Bess's character that is of A Girl Worth Gold. Similarities between the two plays are also detected in the choice of The King of Fez, Mullisheg and Joffer.

\section{THE PLAY AS ADVENTURE DRAMA OR AS PART OF ELIZABETHAN BOURGEOIS LITERATURE}

In Turner's introduction (1968: XV), Nearly all great fictions are fundamentally adventures... adventure drama proper uses incident to cancel matters of philosophical concern. As adventure drama, the play starts with the celebration of the English navy achievements, probably in the post Armada era. Heywood has it that Carrol points out The great success at Cales under the conduct of such a noble general hath put heart into the English. (1968: I-I, 7) By the same token, the captain goes on to declare that the English defeated the Spanish Armada.

He points out:

"How Plymouth swells with gallants! How the streets glister with gold! You cannot meet a man but trick'd in scarf and feather that it seems as if the pride of England's gallantry were harbor'd here." (1968: I-I, 7).

These several real samples confirm that the play is an example of adventure drama. There was first a historical allusion to the English power in the sea. In the play, Carrol asks the followingquestion: Can you not guess the purpose of this voyage? (1968: I-I, 7).

The Fair Maid of the West as an adventure play is nowhere better confirmed than in Bess's request: Bess said: I am bound upon a voyage/ Will you in this adventure like such a part/ as I myself shall do? (1968: IV, II, 64). Any journey of adventure must have a purpose or a motif. In the play, Bess's journey's motif is, for her, 'to fetch the body of my Spencer. (1968: IV,IV, 69)

The Fair Maid has features typical of the Elizabethan bourgeois literature.(1968: XV) Although many of Heywood's works will still remain out of print and seemingly out of mind, as Grace Ioppolo (2014: 127) has it, The Fair Maid of the West is an instance of how a great dramatist and a great actor brands his name.
Heywood, in short, figures prominently as an allcompassing man of the theatre. He was the sole major playwright who had served as a covenanted actor with several companies together with other skills he had as a theatre professional. (2014: 127,128)

What follows of this article aims at pinning down several aspects in relationship with the play in question. The play is pregnant of instances that celebrate the spirit of heroism; which is Elizabethan par excellence. Bess Bridges, A Girl Worth Gold features as superhuman. She is therefore some bright angel that is dropped from heaven (1968: V, I, 78). All are thus authentic instances of the Elizabethan life style. In addition to this, Spencer, The Noble Stranger epitomizes the spirit of heroism and honor in the Elizabethan character.

Following the same line of thinking, Jack D'Amico (1991: 84), in the Moor in English Renaissance Drama, writes: the opening of the play recalled the heroism and excitement of English counterattacks against Spain in the post Armada years.

To initiate into any analytical work of western (mis)representation of Moorish culture and character, Said seems very relevant. In his Orientalism (Said, 1978: 2), he writes defining Orientalism as: A style of thought based upon an anthological and epistemological distinction made between the Orient and (most of the time) the Occident. In brief, the ideology Said seems to advocate hinges upon a binary opposition. One pole is oriental, taken in its broad meaning and the other is occidental, in a representation that is, for the most part, Orientalist. In the same vein, the orient exists in western discourse as an invention, a creation, a representation, hence, a misrepresentation. (Bekkaoui, 1998:16) The oriental is lascivious, backward, over sensual, inaccurate and incapable of change. This is yet an example of what

he calls theatricization of the Orient. On the other hand, the west is rational, developed, humane, and superior. (Said, 1978: 300-301) Given this dyadic image, the orient is at bottom of something either to be feared...or to be controlled. In consequence of this dichotomy portrait of the victorious occident as opposed to the aberrant orient, I will try to display how excellent Heywood had been at sketching out this dichotomy.

By reading the Fair Maid of the West, this article aims at deconstructing the Orientalist stereotype about the alien Moor. The Moor has been measured against western norms (1991:1). To argue that the stage is a space where Orientalist ideology is subverted rather thanconfirmed is another of many objectives for this paper (Bekkaoui, 1998:35). Before embarking on an analysis of the play, 
I will explore some instances of difference in the plot,in particular, between the two parts albeit, many of the devices of part I carry over to part II just as do the major characters. (1968: XVII)

This paper consists of two parts. The first is concerned with the representation of the occidental (western). It offers a close reading of the western heroism and pattern of virtue and a celebration of the dominant discourse over the submissive. The second part deals with the representation of Moorish culture and character in the two parts. It will be an endeavour to spot how lust in the Amorous King of Fez will melt into honor, unprecedented for a Moor. Moreover, this very particular part in the play will trace the emergence of the noble nature in a character like Joffer, who though a Moor proved a noble. In a later stage in this paper, I will try to look at the fact that in Thomas Heywood's play, the main characters carry with them a cultural perspective that is tested but never fundamentally challenged. (1991:98) Western values remain the norm upon which everything is to be measured.

In 'The Racialized Economy of Desire in The Fair Maid of the West', Garcia dramatized the relationship between Moors and Europeans governed by what is described in the article as the economy of desire where he argued that Bess, for example, prototypically represents the first economy of desire and he wrote about how Bess changes clearly towards a much more passive and submissive female. The article also speaks about the mobilization of this desire that would be the driving force in the two parts of the play. The English desire for Money is later balanced by a black desire to the English whiteness. ${ }^{7}$

Thomas Heywood, unlike other Renaissance playwrights who worked out the stereotypical image on Moors, is a good example of the playwright whose style of writing is incomparable. In his writing, we find a playwright who knew more about the Moroccan world and who could use that knowledge to begin a dialogue of cultural perspectives (1991:84) In short, his play is a meeting place for English culture with the Moorish.

\section{THE OCCIDENTAL IN THE FAIR MAID OF THE WEST: THE ENGLISH MAN: A GIRL WORTH GOLD}

Thomas Heywood's play, The Fair Maid of the West, or A girl Worth Gold is an adventure play and a story of romance, where travel does not really teach, but it reveals or confirms existing patterns of virtue in the voyagers. (1991:98, 85) The occidental, the English in our case, though taken captive and oppressed by the Moors, keep up the verses of chastity and honor. In their quest to maintain this image, they are threatened and their self esteem is put into task. Part one is a useful reflection of Elizabethan attitudes in the (16th century in theplay under study).

To begin with, The Fair Maid of the West is the play that successfully portrayed self esteem projected in the characters of Bess and Spencer. (1991: 85-86) These are representatives of English culture, the culture of faith and honour. Part one starts with a celebration of Bess's noble nature. For the captain Bess is not proud. She is windrow modest. Bess, the Elizabethan Cyndrella, is the incarnation of beauty. The captain goes on:

Well, she is a most attractive adamant; Her very beauty hath upheld that house And gain'd her master much. (1968: I.I, 8)

After she had learnt of Spencer's death, she posed questions like: What shall become of me... ?/ My innocence hath been the cause of blood. (1968: I. II, 16) Being true to herself, Bess's chastity will be exposed to question. Goodlack asks Spencer to try her before you trust her (1968: I. III:17). An ideal Elizabethan lady must encounter all sorts of acid tests. Whatever the tests are, Bess keeps her true image. She shall not live to lose Spencer. She shall die, had Spencer not been saved. (1968: I. III, 20)

Once asked to investigate about her chastity, Goodlack pointed out in a way to quench the mayor's thirst of information about her: I was desired to make inquiry / what fame she bears and what report she is of. / Is she such a saint? / None can missay her? These are but questions, for which the answer is the same: Bess hath won the love of all. (1968: III, II, 49)

On their race to gain Bess's heart, every character points to his father or his own achievements. A first case in point is Roughman. I am the Roughman, the only approved, gallant of these parts, / a man of whom the roars stand in awe / and must not be put off. (1968: II. I, 26). Unlike Roughman, Glem comes to praise his father. My father was a baker, by the report / of his neighbors, as honest a man as ever lived by bread (1968: II. I, 23). Her response, however, implies her honesty to her Spencer. Refuting Roughman, she declares that she has never yet heard a man so praise himself, / but prov'd in the end a coward (1968:II. I, 26). For Clem, Bess's refusal is conditioned. He must prove an honest servant, and he shall find his good misteries (1968:II. I, 24).

Part I of The fair Maid of The West is full of other 
instances, where Bess speaks on behalf of English values. Her fame grows in all these seas. The Amorous King of $\mathrm{Fez}$ has learnt of her true nature. The Moors told him that there is a girl worth gold.

In the eyes of Alcade, to describe her/ were to make eloquence dumb (1968:IV, V, 76). This use of imagery makes it undoubtful that Bess is a symbol of beauty and chastity, who will be desired by Mullisheg. Totempt her, Mullisheg is willing to offer great amount of money. Were' $\mathrm{t}$ half by kingdom, / that, beauteous English version, thou shalt have (1968:V. I, 78). This offer is very reminiscent of the experience of the white woman at the hands of Moorish kings. Their angelic beauty is often conceived of a stimulus that triggers the lust in a king. Following the same line of thinking, when Roughman failed to get Bess on his side, he decided to conduct her to Mullisheg's prison straight (1968: V. I, 77). ${ }^{8}$

In front of The Amorous King of Fez, Bess scared and amazed him. I am amaz'd/ this is no mortal creature I behold, / but some bright angel. (1968: V, I, 78). Not fully yet seventeen (1968: V. I, 79), Bess is the prototype of an English virgin who will keep up to the expectation of the Elizabethan public. Mullisheg's fascination by Bess reaches its zenith in part I. In his description of the land, a woman born in England has come from Mullisheg states that English earth may well be term'd a heaven, / that breeds such divine beauties (1968: V. I, 78). She has wakened in me a heroic spirit, the king of Fez declares (1968:V. II, 89).

In front of all of these offers neither Bess nor her followers seek the gold Mullisheg gives to them. My followers want no gold (1968: V. I, 78 ). Bess has to observe and to show off her beauty and virtue. (1991: 88) In the play, Bess only came to thee for my pleasure / and show thee what these say thou never saw' st, /a woman born in England (1968: V. I, 78 ). In brief, Bess, the representative of English culture has never felt short to be the epitome of honesty and chastity. Throughout part I, Bess is never seen at the mercy of the Moors for she can have a set of conditions to emancipate herself and her Spencer. On reading her demands, Goodlacksays in a passage that reads:

"First, liberty for her and hers to leave the land at her pleasure. Next, safe conduct to and from her ship at her own discretion. Thirdly, to be free from all violence either by the king or any of his people. Fourthly, to allow her mariners fresh victual abroad. Fifthly, to offer no further violence to her person than what he seeks by kindly usage and free entreaty". (1968: V. I, 78)

Driven by his desire of Bess, the king will do all his best to gain her heart and quench his lust. Great King, Bess addresses Mullisheg, I'll pay their ransom. His response is thy word shall betheir ransom. Her honesty to Spencer has been put into task again, when Mullisheg sentenced the former to death. Then, he shall die. Honest to her Spencer, Bess states that for these I only spake; for him, I kneel, / if I have any grace with mighty Fez. In response, a kiss shall be his pardon (1968: V. II, 87). In this part I, Bess's beauty and goodness were twin shields against evil and Goodlack could not force himself anymore upon her as the case in part II, where her cuteness jeopardizes her life and makes her a subject for her defloration. (1968: XVIII) The traditional stereotype about the Moor as lustful is played throughout the play but its tone has been reduced later. In this respect, Jack d'Amico (1991: 85) writes:

Though Heywood made use of just enough of the passionate and unpredictable ingredients in the traditional stereotype of the Moor to give the Moroccan scenes dramatic tension, the Moors never pose a serious threat to heroine or hero.

In most of captivity accounts, the western female is to be threatened either by the lust of the captor at best or her countrymen at worst. $^{9}$ Bess did not experience this at least in part I. Elizabeth Marsh, for example, had been harshly undergone this. The Misfortunes I met with in Barbary ... have been more than equaled by those I have since experienced in this land of civil and religious liberty. (Bekkaoui Ed., 2003: 41)

Her chastity has been jeopardized and she could hardly escape what she had suffered on account of passing for what I really was not (Bekkaoui Ed., 2003: 117). Bess, in contrast, has fled these critical moments in the female captive's life there in Barbary. As touched upon earlier, Bess's beauty became stimulus to defloration in part II. These changes in the moral tone of the play will make part II a less innocent and a less vigorously healthy play than part I. (1968: XVIII)

Bess's spirit, in part II, goes on to be the stimulus to whoever comes to contact with her. Mullisheg, on being spellcast by this divinest mistress (1968: Part II. V. II, 182), confirms ourfirst claim protect that Bess will be a source of temptation. For him, she is the only lady on earth, who can satisfy his desire. Mullisheg points out that venetian ladies, nor the Persian girls, / The French, the Spanish, nor the Turkish dames, / Ethiope nor Greece can kiss withhalf that art. But in his eyes These 
English can (1968: II. I, 136). Bess, regardless of being artistic in kissing, becomes like a heartless creature, a body without motion. (1968: III. II,140). Back to part I, the kiss is mis-interpreted from one culture to the other. For the English, It is a garb of entertainment, given that the first greeting begin's still on the lips. Differently put, there is no shame for Bess to kiss a king. (1968: Part II. V. I,79). The ultimate end of this is that Mullisheg, the representative of the exotic, mistakes the customs of the English while Bess sets to the standards (1991: 88). No matter what the deeds she has committed, she remains a fair mistress. (196: Part II, IV. VI,170).

During her journey to liberate her Spencer, Bess, once released from the hands of the Moors, falls prey to the bandit who intends to ravish thee. His black purpose failed in cradle after the intervention of the Duke of Florence. The western Bess exclaims: what rape intended? / I had not thought there had been such a mischief / devis'd for a wretched woman. (1968:IV. I, 15). Her good luck contributes to her escape from the hardships of captivity. Florence, because he

has witnessed Bess's fine nature, ${ }^{10}$ speaks of her as the fairest of thy sex...because I read a nobleness in thy forehead (1968: IV. I, 156). Bess is the sublime creature, to use Hardy's words describing Tess in Tesss of the D'Urbervilles, whose chastity conquer'd his( Mullisheg's) lust and maugre his incontinence, / made him admire her virtues (1968: IV. I,158). A re-reading of this will only confirm the metamorphosis of the moral tone the play undergoes. Her beauty becomes but a stimulus that extracts the saliva of the Moor.

Her captivity in Barbary must have been critical, where Bess bursts into tears whenever she comes to remember that experience there in. 'I cannot speak it without tears' is her response to Florence's request to have her Spencer's story told at his presence, (1968: IV. I,158) Though being tortured throughout the play, Bess excels in keeping up her sublime nature. This is nowhere best exemplified than in the last words of the play. The fairest maid me'er pattern'd in her life, / so fair a virgin and so chaste a wife. (1968: V. IV, 196). In brief, Bess, together with Spencer, remains a pattern of virtue (1968: 85) given that their values must triumph ${ }^{11}$ because power, chastity and honor remain English. In the following section, I will shed light on the hero of the piece, whose values are in common with Bess's.

\section{THE ENGLISHMAN IN THE FAIR MAID OF THE WEST}

In most regards, western values must represent the norm. (1991: 91) Their values are to be questioned but never challenged. Although taken captives, the English men are never the aliens; their values must remain the basis for all judgments. For Heywood, he knew how to fascinate and excite his audience, but he assured them that trusted beliefs would not be seriously challenged and for Spencer he is at worst a noble stranger. (1991: 86) Spencer, a representative of English culture, becomes a legendary figure, whose virtues even barbarous Moors admir'd. Bess is much proud of her husband. About the dangers he has passed, Bess points out: This man for whom a thousand dangers / I've endur'd, of whom the best approved / chroniclers might write a golden legend (Part II. V. IV, 193). He remains the noble Saracen, (1991: 76) whose honesty, faith and religion are all engag'd. (1968: V. II,18).

$\mathrm{He}$ is to sacrifice love to keep the honour of his country. For a hero like Spencer, he is to meet Allah but to spare the honour and faith of his country. I'll sell myself. And if my wealth will not / Amount so much, I'll leave myself in hostage. (1968: V. IV, 195). A gentleman, Spencer values the honour of his culture than his life. He does not fear death. An English virtue thou shalt try, / that for my life once didst not fear to die (1968: V. IV, 195). When it preys on his mind, that he should not let Joffer, the noble Moor, to his fate, Spencer comes to save his face.Though he made of Joffer the instrument to the court gates, Spencer regrets whatever words he uttered in favour against the Moors, and whatever deeds he used to risk the honor of Christians. ${ }^{12}$ At the end, he meets his sanity. At last, the public is convinced that such honor is not found in Barbary (1968: V. IV, 195) and Florence, having seen this, made him, together with his Bess, pass to thy country ransomless and free.(1968: V. IV, 195).

These true virtues have been questioned throughout the play. Alcade, for example, speaking on behalf of the Moorish court, describes the Christians as colonizers. Those Christians that reap profit by our land, / should contribute unto so great a loss (1968: IV. III, 68). This situation induces Joffer to refute being used as the instrument $^{13}$ at the very outset, albeit he admires the person of Spencer. To him, who thou he may admire and love you yet cannot help you. (1968: II. VI, 131). Spencer's noble deeds' are plausible reasons to convince Joffer to help his escape together with his Bess. His gentlemanliness becomes sacred. I swore by the honor of a gentleman (1968: II. VI, 134). I have argued earlier that white remains the colourof virtue, for most swans are white (1991: 94). Let in some equivocal instances, this norm has been put into question. Alcade, again, points out, reconstructing the image of the west (England/ English): I much suspect; these English amongst themselves are treacherous. (1968: 
II. IV, 128). At the end of the play, as in Said's Orientalism, we have witnessed the west triumph over the orient. All moral virtues are solely grounded in the hearts of Christians. ${ }^{14}$ Though the other reading of the play will prove otherwise, Spencer remains the noble stranger who was ready to throw his soul in glory of his honor.

In The Fair Maid of the West, the examples are many of those who epitomize the English virtue. Once in Barbary, all the representatives of the west desire to save the face of Englishness. Who is to save them? Who is to ransom them? Goodlack comes at first. What's done is mine, I here confess' $d /$ then seize my life in ransom of the rest (1968: III. III, 149) andI therefore first should die (1968: III. III, 150). Goodlack, as the name connotes turns to be a symbol of sacrifice. He is, therefore, a representative of the culture of honor and virtue. This ebb and flow in the representation of the west ends up by giving answers to half of Mullisheg's questions: Shall Christians have the honor to be sole heirs of goodness? (1968: III.III,151).

\section{ONE CENTER AND MANY WESTS}

As Lawrence Dawson puts forward that English drama suggests some ways in which the English idea of Islam had to encompass a range of otherness, Heywood's play seems to be a meeting place of the various parts of the occident. Heywood, inspired by his sense of belonging to the English race, seems to be biased, to my own view, in favour of his nation.

About the English man, Heywood has that Tota, Mullisheg's spouse, admires them. In the play, she confesses that she'll marry one/ of this brave nation, if a gentleman. They are such sweet and having bed fellows (1968: III. I, 136). Dawson's critical analysis of these stories complicates the idea of a monolithic Englishness versus a subaltern Islamic Empire (Dawson, 2002: 4).

On the other hand, the Spaniards are badly depicted in the play. Here's no security, / for when the beaten Spaniards shall return, they'll spoil whom they can find (1968: II. $\mathrm{V}, 40$ ). If England is the heaven, Spain is sketched out as the hell, for its safety. In the same vein, Heywood also presented the Italians at a later stage in the play. The biased discourse of the English is confirmed in Goodlack's speech about the Italian race: Be aware of these Italians, / they are by nature jealous and revengeful (1968: IV. VI, 172). The standard by which the world is judged is therefore English, whereas any exposure to the foreign, non-English and even non-protestant must be challenged. (1991: 85) The challenge seems to be therefore against Muslims and Catholics.

\section{ONE ORIENT OR MANY: THE ORIENTAL AND THE MOOR}

Has the west been represented as the possessor of power, the advocator of the oppressed and the true representative of honour and virtue, the Moor in The Fair Maid of the West wavers between lust and nobility. (1991: 85) In this respect, the stereotype of the Mooras lascivious is confirmed then reconstructed. The Moor as the villainous pagan takes a new form of the noble Moor. ${ }^{15}$

Throughout history, the word Barbary implies the land of captivity and rape. This is very factual in the piece under study in that Heywood's very first reference to Barbary has been associated with piracy and captivity. The surgeon speaks: We have a ship, / of which I am surgeon, that belongs unto a London merchant, now bound for Mamora, / a town in Barbary. (1968: II. V, 40). The analogy, to my own understanding, is often drawn between Barbary, as a land of captivity and Catholic Spain and Rome as lands of rape. Roughman, trying to persuade Spencer to save Bess from the bandit, points out: I left her in the hands of rape and murder. ... revenged her on that villain. (1968: IV. VI, 175). At the very outset of phase the first, Morocco, Barbary, is described as the land of captivity par excellence. The merchant points out in a passage that reads as: I am a London, bound for Barbary, / but by this Spanish man of war surpis'd, pillag'd, and captiv'd. (1968: IV. IV, 74). Barbary is also presented as a land of wealth. Mullisheg uses phrases like: Mamorah's wealth / The gold coin'd in rich Barbary (1968: V.I,80).

\section{THE MOOR AND THE STEREOTYPE}

A major goal of this article is to examine how the Renaissance Moor is stereotypically represented as barbarous, infidel, devil though the tone of these negative images has been reduced to meet the requirements of self interest. (1991: 7) The Moor as villain turns to be a suitable locus for those dark forces that threaten European society. (1991: 2) I should point out that there moments where the other can take this power to dominate used in western narratives can be subverted and could be used to generate forms of spectacular resistance, to borrow Khalid Bekkaoui's book title Signs of Spectacular Resistance.

The image of the Moor takes one monolithic form as the quintessential strange, an object to be feared. (1991: 77) This stereotype on the moor is nowhere better presented than in the character of The Amorous King of Fez, Mullisheg. We are introduced to a king who is tainted 
by greed and lust. The stereotype reaches its nadir, when the king of Fez and great Morocco is driven by his desire to lie with Bess. For Mullisheg, What's the style of king/ without his pleasure? Throughout, he keeps asking for concubines, you can hire or buy for gold. He draws an image of the king so stereotypical in its construction. He goes on: If kings on earth be termed demigods, why should we not make here terrestrial heaven?... Our God shall be our pleasure. (1968: IV, III, 68). Willing for sacrifice, Mullisheg offers a lot of money to gain the heart of Bess. Were't half my kingdom, / that beauteous English virgin, thou shalt have. (1968: V. I,78). His language seems over sensual, contributing to confirm the truthfulness of the stereotype of the lustful Moor. Addressing Bess, he states: Let your presence beautify our throne. (1968: V. I, 81). Bess felt the dangers Mullisheg may cause her. She points out: Mighty prince, if you desire to see me beat my breast, / pour forth a river of increasing tears, / then you may urge me to that sad discourse (1968: V. I, 79). This is reminiscent of the representation of Islam in most Orientalist writings. Islam is depicted as a religion that invites sensuality, and seldom do we encounter a dramatist trying to understand the aspects of a religion on its own. (1991: 81) In this framework, we should acknowledge that the version of Islam, like this, must be a religion of pleasure. The result is, as a matter of fact, the creation of theatrical identities. (1991: 84) This stereotypical depiction remains prototypical not because the English have been granted the power to see the Moroccan society, but the Amorous King of Fez can see an English woman. (1991: 88) Interestingly enough, the Moor of Fez is ready to give his wealth just for a kiss. In the fear that Spencer would turn the Moors to Christianity, Mullisheg sentenced him to death. By the intervention of Bess, her word shall be their ransomat first and a kiss shall be his ransom. (1968: V. II, 87). By the end of part I, however, some change has been observed in the character of the king; which goes on through part II. He speaks to Bess: You have waken'd in me an heroic spirit; / lust shall not conquer virtue. (1968: V. II, 89)

However, the construction of the stereotype about the Moor is passed on to part II. The very first words in this part initiate to the situation of the Moorish harem, the victims of the king of Fez. Tota, the king's wife, representing this genre, castigates her status quo: It must not, may not, shall not be endur'd. / Left we fore this our country? To be made/ A mere neglected lady here in Fez. (1968: Part II. I. I, 97). For the poor lady, Mullisheg will pollute Bess's innocence. She has also contributed to keep up these stereotypes, when she declares that the Moors are treacherous, / and then we dare not trust.
(1968: I. I, 98).

Tota's judgment goes in line with Goodlack's. In part II, he perpetuates the same stereotype of the Moor as treacherous: We are not safe, lieutenant. Moors are treacherous. (1968: I. I, 115)

Being lascivious is not a mere stereotype attached to the Moor, but the entire stereotype willbe bequeathed to the Moorish queen. ${ }^{16}$ Tota is also running after her lust. She refutes her husband, given that she cannot love him. Thinkest thou I could love a monkey, a baboon. (1968: I. I, 103 $)^{17}$. She, like Mullisheg, is willing to buy herself a Saracen. Trying to convince Roughman, she declares that she'll make him rich. (1968: I. I, 102). She will pay, but Roughman must woo Spencer to embrace the queen. (1968: I. I, 114).

Heywood describes this threat as resulting from the Moorishness of both the queen and the king. (1991: 89) In the same vein, Clem, in Part II, reminds the public that darkness is a symbol of the devil's generation in an attempt to confirm that stereotype of the blackcomplexion. Addressing Tota, he states: I'll see/ you damn'd as deed the black father of your generation. (1968: I. I, 101). In brief, the black colour is a generator of devil. This blackness will push Spencer to use the same reference to convince Joffer to help him. If you ever loved or such a maid/ so fair, so constant, and so chaste as mine ..... betray her to a black...? (1968: II. VI, 133). This stereotype is well worked out in that Goodlack, trying to convince Spencer not to come back to Barbary, says: What's the lives of twenty thousand Moors/ to one that is Christian? (1968: III. II, 144). The construction of this same stereotype reaches its zenith when Spencer comes to the conclusion that there is some similarity between Mullisheg's black visage and his soul. His lust outweigh'd his honor, and as if his soul were blacker than his face. (1968: II. VI, 134)

A reading of Heywood's The Fair Maid of the West, Parts I and II would make use of how the Western stereotype of the Moor has produced the other as lascivious and over-sexual and could ultimately heighten up this stereotype to produce an image of the Moor as a producer of power. The Moor is no more absent in the drama for the first time. He has attained massive visibility as opposed to the Orientals Said discusses in his Orientalism. (Bekkaoui,1998: 104) The Moors, in Heywood's the Fair Maid of the West, are permitted more space for self- expression and self-realization. The alien Moor will become the noble Moor, as ample evidence that he is also capable of good deeds. This noble Moor as a type steps into the frame provided by Venice. (1991: 163) It is the communal arena that 
welcomes strangers either to the state or to the society. The examples are many, starting from Eleazar to Othello, the noble Moors.

In our case, Mullisheg does no more desire to be thy breast companion (1968: II. II, 124). He becomes more royal. Heywood has it that Mullisheg is no more lustful. Shall lust in me have chief predominance? ... Shall Christians have the honor/ to be sole heirs of goodness, and we Moors/ Barbarous and bloody? (1968: III. III, 151) the amorous king asks. We are now introduced to a Mullisheg, who is apt to change. Speaking to Bess, Mullisheg points out: " $y$ ' have quenched in me all lust, by which shall grow/ virtues which Fez and all the world shall know. (1968: III. III, 151). This new image of him shall be reported to the English public. Spencer promised him that they shall report your bounties, and your royalties/ shall fly through all the parts of Christendom. (1968: III. III, 152).

The ambivalence in the representation of the Moor begins namely in part II. The first words of justice to be uttered in favour of him are those of Clem: First and foremost, I have observed the wisdom of these Moors. (1968: II. I, 117). Now, we are introduced to a new version of Mullisheg who boasts that our words are acts, our promises are deeds/ we do not feed with air. (1968: I. I, 109). Mullisheg has become a Moor whose tongue reveals what (t) his safe darkness hides. (1968: II. II, 124).

Following the same line of thinking, Heywood's use of the stereotype becomes opaque in its mode of narration. In part II, Heywood represents his hero, Spencer, and a Moor Toffer in competition with one another in honor. (1991: 89) Joffer, the noble Moor, is used in the play to deconstruct the stereotype of the devilish Moor. He will demonstrate that all moral virtues are not solely grounded / in the hearts of Christians. (1968: III. I, 135). Differently put, Moors are also capable of being noble like the Christians. This is nowhere presented than in the character of Joffer, who though a Moor, / a nation strange unto you Christians, / yet that I can be noble. (1968: II. VI, 132).

Although Spencer seemed to have had bad intention to make him (Joffer) the instrument, he would regret later. For him, this man, whose office was to keep me, shall/ be the only means to free me. (1968: II. V, 129). Spencer's tears have been triggered, for Joffer has pitied the dangers the former has passed. You have deeply touch'd me. (1968: II. IV, 134). This honourable favour on the part of the Moor poses various questions to Spencer and the English values are put into task. Spencer asks: Is honor fled from Christians unto Moors, / that I may say in Barbary I found/ this rare black swan? ${ }^{18}$ (1968: III. I, 135). Though black, Joffer's manners, heart and soul are white. Spencer fell victim in front of Joffer.

He exclaims: Shall Fez report unto our country's shame and to the scandal/ of our religion that a Barbarous Moor can exceed us in nobleness. No, I'll die/ a hundred thousand deaths first. (1968: III. II, 144)

Heywood has it that Joffer will sympathize with Spencer and Bess and help them pass free but her sense of superiority pushed her to turn her Spencer upon the poor Moor. Earlier in this analysis of the two part of the play, I have argued that this western sense of superiority and honor has been put into question. Mullisheg accuses Joffer of being stupid, telling him that the Christian hath broke faith. (1968: III. III, 14) Is honor fled from Christians unto Moors? (1968: III. I, 135) Put in a nutshell, the Moor as devilish is substituted for the noble Moor. Ina play of adventure, the comic spirit will prevail and Mullisheg meets his better inner-self. (1991: 95) When they were at the hands of the Duke of Florence, there was an argument between Bess and Spencer about the new noble Moor. Are they to let him meet his fate? If so, the honor of Christians must be in crisis. The Moor awaits his ransom. Florence states that although a prisoner captive and a Moor, yet, use him like the noblest of his nation. Being so noble, they will negotiate his ransom. (1968: V. IV, 189)

Being the replica of western values, Joffer has been offered a ransom. Though the lives of twenty thousand Moors do not match with the life of one Christian in the eyes of the English public, Heywood, later in part II, will revise this image. The life of a Christian is worth the life of a Moor. Spencer is the noble stranger and Joffer is the noble Moor. They are thus friends, about whom Joffer vents himself: were I in freedom and my princely honors, I should/ then be proud to call you Spencer and my friend. (1968: V.IV, 195). In response to Joffer's endurance, Spencer, minimizing his anxieties, states:

An English virtue thou shalt try,

That for my life once didst not fear to die, Then for his noble office done to me...

... Myself, my friends and all my fortune, May redeem him home, unto my naked skin

I'll see myself and if my wealth will not

Amount so much, I'll leave myself in hostage. (1968: V.IV, 195)

Yet, this scene is much of a portrait of differences that are ultimately reconciled. This reconciliation of opposing cultures is satirical to some extent, with the English as the ultimate arbiter of value. (1991: 92) Put differently, 
the English stands out to be the prototype upon which everything holds to be judged. For Joffer, the sympathy Spencer shows towards him is mainly derived from Christendom. Such honor is not found in Barbary. (1968: V.IV, 195)

From my own perception, this meeting between the two cultures and this mutual understanding is the outcome of a new vision to the world. That is, the Moor can be noble and of a sublime nature, were he to abide by the western standards. Satirically enough, the Moor of the piece can be noble but to rid himself of his race and his culture so as to meet his inner virtue. (1991: 96) In line with this, Joffer meets the new faith, due to the bravery Spencer exhibits. The virtue in these Christians hath converted me. / ... Accept me, then, a Christian and a brother. (1968: V.IV, 195) Such are the very last words in the play, but a set of questions are asked: Is It true that the noble Moor emulates an English hero? Does it confirm the superiority of the European tradition? Does it keep up the eastern values inferior? Does Heywood allow Joffer to speak at the end to confirm the victory or the defeat of the Moorishness? Has the Moor been granted a voice to speak last and best? Has honor fled from Christians unto Moors?

\section{ENGLAND AND OUR FEZ: HOW DO OUR PEOPLE DIFFER (1968: 100)}

If Orientalism sets differences between the west and the orient, Heywood comes up with thesenew cultural zones for better dialogue. His The Fair Maid is a meeting place and a locus of two opposing cultures, competing for honor. Yet, these opposing cultures once compared,the orient fell short ultimately. On drawing the analogy between the two, Clem vents his opinion:

Our countrymen eat and drink as yours do for all the world; open their eyes when they would see and shut them again when they would sleep; when they go, they set one leg before another; and gape when their mouths open, as yours; eat when they have stomachs, scratch when it itches. Only I hold my nation to be the cleaner because they never set down to meet with such foul hands and faces. (1968: I. I, 100)

This theatrical representation is very reminiscent of Orwell's representation of people of Marrakech; which is very stereotypical. In his article, he writes it is always difficult to believe that you are walking among human beings. (Orwell, 1939: 61) That is, his image is much a representation on stage than on reality. In his Orientalism, Said also describes how the orient was constructed by the west. For him, this representation of this construct is part of a general European attempt - from Bede to Luther - to put a representative orient in front of Europe, to stage the orient and Europe together in some coherent way ... Islam was a misguided version of Christianity. (Said, 1978: 61, 62) For Heywood himself, he tried all means to sketch out two opposing ideologies, in a setting so much familiar to the European public, trying to meet. Heywood has managed in constructing a setting- albeit theatrical- where the noble Christian isin a combat with the devilish Moor. Rather, a meeting place is set for them to negotiate differences and settle disputes and race to defeat lust and build up for virtue. Yet, Heywood, albeit excellent in dramatization, fails to maintain a substantial impartiality neural. His discourse remains biased to the pole of power. $\mathrm{He}$, on his part, is an Orientalist par excellence, for he sides with the dominant discourse, the English, at the expense of the obedient, the oriental. Had he uttered a word of justice for Moors, he would not have been entitled an Orientalist like Shakespeare, Marlowe and Dryden. (Bekkoui, 1998: 36) Heywood draws an analogy between the west and the orient, but his success is still questionable, because for an oriental

to uncover his true virtue, he must rid himself of his own culture. To be noble, you must be an English protestant. Joffer's conversion is therefore celebrated as he has liberated himself fromthe religion of pleasure to embrace the new faith of the noble Saracens, to use his words.

\section{CONCLUSION}

In Heywood's version, the Islamic Moor had, at last, to be judged as more than a simple Barbarian, no longer a pagan in need of conversion. (1991: 75) His The Fair Maid of the West, part I and part II articulates the aggressive struggle between the west and the orient. This struggle is, however, minimized and curtailed to a small proportion. The Moor is amorous and lustful in part I, but in the second, he becomes a noble Moor, who is capable of firing back and creating his own counternarrative.

The west Heywood envisages remains the standard of judgment. It is the west of Bess, a girl worth gold and the west of Spencer, the noble stranger. The west which is incarnated in the teacher, as in Orientalism sermonizes the best values of virtue and honor. On the other part, Heywood makes use of an orient that is so much a student to emulate the western heroes. In the play, Mullisheg confirms this claim: those virtues you have taught us by your deeds, we futurely will strive to imitate. (1968: III, III, 152). This is part of what I would call gaps inherent in western narratives or they might be described as counter-stream narratives as Said and his critics would 
always like to describe it.

In The Fair Maid of The West, we are introduced, for the first time, to a dramatist who puts much of the ingredients of the traditional stereotypes about the Moor into use and in a later stage of the play, he presents the western values agonizing. Heywood's play is therefore the acid test for Christian values. These values have been tested every now and then throughout the narrative but never challenged. The western values are ultimately the standards of measurement. When the amorous king of Fez takes a kiss on Bess's lips, he is mocked as the lustful and the lascivious moor, but Bess, the fairest of her sex, is said to have set to the standards.

This comic reconciliation between the westerner and the oriental is so much a caricature of a cultural dialogue Heywood is so keen on advocating. The imaginary dialogue comes in favour of one part, at the expense of the other. Heywood, albeit he presents his occidental hero in competition with a Moor in honor, privileges the faith of Christianity and diminishes Islam, the religion of pleasure, for him. He tried to give birth to a world in harmony, but all deemed to failure, in a representation of the Moor stereotypical at best and Orientalist at worst.

\section{ENDNOTES}

${ }^{1}$ Emphasis is mine.

2 Heywood, Thomas. The Fair Maid of The West. Ed. By: Robert K. Turner, Jr. N. (University of Nebraska Press, 1968 ), IX. All citations are to be taken from this edition. The use of prose here should be compared to Shakespeare's poetry.

${ }^{3}$ Williams. 'Stolne and Surreptitious': Heywood as a Test Case in Early Theatre (17.2. 2014),135. He was speaking about the process of stenography.

4 Ioppolo. 'Thomas Heywood, Just in Time' in Early Theatre', 123. Together with The Fair Maid of the West which has received wide critical attention, Heywood's plays about women and which include other female-titled plays The Wise Woman of Hoxton, The Fair Maid of the Exchange, The Rape of Lucrece, and A Maiden-head Well Lost, as well as his three prose histories of notable women England's Elizabeth, her Life and Troubles, Gynaikeion, or, Nine Books of Various History Concerning Women, and The Exemplary Lives and Memorable Acts of Nine the Most Worthy Women of the World have received less critical attention. See the same article, 123.

5 For this question of editorial treatment, see William Proctor Williams' 'Stolne and Surreptitious': Heywood as a Test Case in Early Theatre 17.2. (2014). This article investigates the means by which piracy could have been done and provides an initial testing of such theft using a small portion of the text in performance", 134.

6 This play was edited by the Moroccan editor: Khalid Bekkaoui. (2001)

${ }^{7}$ For more details on the logic of desire inherent in the play, see Luciano García García. 'The RacializedEconomy of Desire in The Fair Maid of the West, (Studia Neophilologica, 88:1), 5669.

8 Dawson writes in 'England, Islam, and the Mediterranean Drama: Othello and Others' in Journal for Early Modern Cultural Studies, Volume 2, Number 2, (Fall/Winter, 2002) that "in the royal court of Fez are certain Christian captives, being partly Spanish and partly Portugal women, who are most circumspectly kept by certain Eunuchs, that are Negro slaves; a Moroccan King keeps white slaves who are" also kept behind the bars, 17.

9 - Take the example of Marsh and others.

10 - A phrase Thomas Hardy uses to describe Tess of D’Urbervilles.

11 - In Orientalism, power is at the hands of the west.

12. The question here is religious rather than racial.

13 - In the play: "I'll make him the instrument". (1968: II. $\mathrm{V}, 129)$

14 - In the play: "All moral virtues are not solely grounded in the hearts of Christians" (1968: III. I, 135)

15 - I mean Joffer here.

16 - This is very reminiscent of the Queen Mother in Lust's Dominion.

17 - This reminds us of the use of the French word "Magot" (Monkey)

18. The black swan was rare.

\section{REFERENCES}

[1] Heywood, Thomas (1968). The Fair Maid of The West. Ed. By: Robert K. Turner, Jr.. University of Nebraska Press

[2] Bekkaoui Khalid (1998). Signs of Spectacular Resistance. Casablanca: Imprimerie Najah ElJadida.

[3] Dauncy, John (1662). The English Lovers. Or, A Girl Worth gold. London

[4] D'Amico, Jack. (1991). The Moor in The English Renaissance Drama. Tampa: University of South Florida Press.

[5] Dawson, Lawrence (Fall/Winter, 2002). 'England, Islam, and the Mediterranean Drama: Othello and Others' in Journal for Early Modern Cultural Studies, Volume 2, Number 2.

[6] García, Luciano García. 88:1, 56-69. 'The Racialized Economy of Desire in The Fair Maid of the West, Studia Neophilologica,

[7] Ioppolo, Grace. (2014) 'Thomas Heywood, Just in Time' in Early Theatre 17.2 
[8] Jowitt, Claire (MUP: 2003). Voyage Drama and Gender Politics

[9] Jowitt, Claire. (2010)The Culture of Piracy, 1580-1630: English Literature and Seasborne Crime. Ashgate

[10] Marsh, Elizabeth. The Female Captive. Ed. Khalid Bekkaoui. (2003) Casablanca: ImprimerieNajah El Jadida.

[11] Matar, Nabil. (1991), Turks, Moors, and Englishmen in The Age of Discovery. New York.

[12] Marsh, Elizabeth (2003). The Female Captive. Ed. Khalid Bekkaoui, Casablanca: ImprimerieNajah El Jadida.

[13] McJannet, Linda, Kolb, Justin, Cannolly, Annaliese, Slotkin, Joel, and Ghatta, Javad. (2009), 'Early Modern English Drama and the Islam World' in Early Theatre 12.2.

[14] Orwell, George (1939). 'Marrakech'. First published: New Writing, GB, London, Christmas.

[15] Said, Edward. (1978). Orientalism. London: Routledge and Kegan Paul.

[16] Sebek, Barbra. 1998, 'Strange outlandish wealth': Transglobal commerce in The Merchant's Mappe of Commerce and The Fair Maid of the West, Parts 1 and 2. In John Gillies \& VirginiaMason Vaughan (eds.) Playing the globe: Genre and geography in English Renaissance drama, 176-202. London: Fairleigh Dickinson University Press,.

[17] Williams, William Proctor (2014). 'Stolne and Surreptitious': Heywood as a Test Case in Early Theatre 17.2.

[18] Wright, Louis B. (1935). Middle Class Culture in Elizabethan England. Chapel Hill: University of North Carolina Press. 